\title{
PENGARUH CAPITAL ADEQUACY RATIO (CAR) DAN BIAYA OPERASIONAL PER PENDAPATAN OPERASIONAL (BOPO) TERHADAP NON PERFORMING FINANCING (NPF) DI BPRS INDONESIA PERIODE 2014-2018
}

\begin{tabular}{l|l|l|} 
& Farid Faisal & \\
& risal.faisal12@ gmail.com \\
& Universitas Suryakancana \\
\hline Masuk: Januari 2021 & Penerimaan: Februari 2021 & Publikasi: Maret 2021
\end{tabular}

\begin{abstract}
ABSTRAK
Penelitian ini dilatar belakangi dengan fenomena nilai NPF yang terus mengalami kenaikan padahal saat bersamaan nilai CAR mengalami kenaikan dengan batas limit yang ditentukan oleh ojk yakni sebesar 8\%. Disisi lain nilai BOPO mengalami kenaikan sedangkan nilai NPF terus mengalami kenaikan melebihi batas limit yang telah ditentukan oleh ojk yakni sebesar 5\% pada Bank Pembiayaan Rakyat Syariah (BPRS) di Indonesia pada periode tahun 2014-2018. Metode penelitian yang digunakan adalah metode penelitian deskriptif dan asosiatif yang menggunakan pendekatan kuantitatif. Populasi yang digunakan adalah data rasio keuangan CAR, BOPO dan NPF Bank Pembiayaan Rakyat Syariah seluruh Indonesia. Pengambilan sampel menggunakan metode purposive sampling dengan jumlah sebanyak 60 sampel. Data yang digunakan adalah data sekunder yang diperoleh dari situs resmi www.ojk.go.id melalui Laporan Keuangan Publikasi Bank Pembiayaan Rakyat Syariah di seluruh Indonesia periode tahun 2014-2015. Hipotesis dalam penelitian ini adalah: $\left(\mathrm{Ha}_{1}\right)$ terdapat pengaruh signifikan variabel Capital Adequacy Ratio (CAR) terhadap Non Performing Financing (NPF) pada BPRS Indonesia, $\left(\mathrm{Ha}_{2}\right)$ terdapat pengaruh signifikan variabel Biaya Operasional Per Pendapatan Operasional (BOPO) terhadap Non Performing Financing (NPF), $\left(\mathrm{Ha}_{3}\right)$ terdapat pengaruh signifikan antaran variabel CAR dan BOPO terhadap Non Performing Financing (NPF). Hasil penelitian menyimpulkan bahwa variabel CAR berpengaruh signifikan kearah negatif terhadap NPF BPRS di Indonesia. Hal ini dibuktikan dengan hasil uji $\mathrm{t}$ variabel CAR terhadap NPF menunjukkan nilai hitung $-7,371>t$ tabel $-1,672$. Variabel BOPO berpengaruh signifikan kearah negatif terhadap NPF BPRS di Indonesia, hal ini terbukti dengan hasil uji t variabel BOPO terhadap NPF menunjukkan nilai $\mathrm{t}$ hitung $-3.778>\mathrm{t}$ tabel $-1,672$. Variabel antara CAR dan BOPO secara simultan berpengaruh signifkan terhadap NPF BPRS di Indonesia, hal ini dibuktikan dengan hasil uji f statistik bahwa CAR dan BOPO secara bersama-sama berpengaruh terhadap NPF, dengan memperoleh nilai $\mathrm{F}_{\text {hitung }}$ sebesar 43,223 > $\mathrm{Ft}_{\text {abel }} 3,160$ dan nilai signifikansinya $0,000<$ 0,005 . Serta CAR dan BOPO memberikan pengaruh sebesar 60,3\% sedangkan sisanya sebesar $39,7 \%$ merupakan pengaruh dari faktor-faktor lain diluar penelitian.
\end{abstract}

Kata Kunci : Bank Syariah; BPRS; CAR, BOPO; dan NPF. 


\begin{abstract}
This research is motivated by the NPF value phenomenon, which continues to increase even though, at the same time, the CAR value has increased with a limit set by OJK, which is 8\%. On the other hand, the value of BOPO has increased while the value of NPF has continued to grow beyond the limit set by OJK, which is $5 \%$ in Sharia Rural Banks (BPRS) in Indonesia in 2014-2018 period. The research method used is descriptive and associative research methods that use a quantitative approach. The population used is the financial ratio data of CAR, BOPO and NPF of Sharia Rural Banks throughout Indonesia. Sampling using a purposive sampling method with a total of 60 samples. The data used is secondary data obtained from the official website www.ojk. go.id through the Financial Reports of Islamic People's Financing Banks throughout Indonesia for 2014-2015. The hypotheses in this study are: (Hal) there is a significant effect of the Capital Adequacy Ratio (CAR) variable on Non-Performing Financing (NPF) in BPRS Indonesia, (Ha2) there is a substantial effect of the Operational Cost Per Operating Income (BOPO) variable on Non-Performing Financing (NPF), (Ha3) there is a significant effect between $C A R$ and BOPO variables on Non-Performing Financing (NPF). The study results concluded that the CAR variable has a significant adverse impact on the NPF of $B P R S$ in Indonesia. This is evidenced by the results of the t-test for the CAR variable on the NPF, which shows the value of -7.371> t table -1.672. The BOPO variable has a significant adverse effect on the NPF of BPRS in Indonesia. This is evidenced by the results of the t-test for the BOPO variable on the NPF, which shows the value of $t$ count -3,778> $t$ table -1,672. The variable between CAR and BOPO simultaneously has a significant effect on the NPF of BPRS in Indonesia. The $f$ statistical test results evidence that CAR and BOPO together impact NPF by obtaining a Fcount of 43.223> Ftable 3,160 and a significance value of 0.000 $<0.005$, as well as CAR and BOPO, have an effect of $60.3 \%$ while the remaining $39.7 \%$ is the influence of other factors outside the study.
\end{abstract}

Keywords: Islamic Bank; BPRS; CAR, BOPO; and NPF.

\title{
A. Pendahuluan
}

Perbankan syariah merupakan lembaga keuangan yang menawarkan sistem bagi hasil dari rasio keuntungan dan kerugian usaha yang dialami. Berdirinya perbankan syariah ditengah perindustrian keuangan konvensional menambah warna di industri perekonomian Indonesia yang diyakini memiliki pengaruh signifikan terhadap pesatnya perkembangan industri keuangan (Husaeni, 2017a). Perkembangan ekonomi syariah atau perbankan syariah di tanah air ditandai dengan berdirinya perbankan syariah pertama di Indonesia pada tahun 1991 yakni Bank Muamalat yang didirikan oleh Majelis Ulama Indonesia beserta Tim Perbankan MUI melalui hasil lokakarya MUI pada tahun 18-20 Agustus 1990. Hingga pada tahun 1992 tepatnya 1 Mei Bank Muamalat resmi beropresi di Indonesia.

Pengembangan perbankan atau ekonomi Islam telah diadopsi ke dalam kerangka besar kebijakan ekonomi di Indonesia. Sebagai salah satu pilar penyangga 
dual banking system dan mendorong pangsa pasar bank-bank syariah yang lebih luas sesuai cetak biru perbankan syariah (Bank Indonesia, 2002). Maka, bank Indonesia sebagai pemegang otoritas perbankan di Indonesia selain OJK menetapkan bank syariah dalam dual banking system dibawah pengawasannya. Selain Bank Umum Syariah (BUS) salah satu lembaga perbankan syariah yang ikut dalam kontribusi mendorong perkembangan ekonomi Islam di Indonesia adalah Bank Pembiayaan Rakyat Syariah (BPRS).

BPRS merupakan salah satu lembaga keuangan yang memberikan kontribusi dalam mengembangkan perekonomian Islam di Indonesia (Husaeni, 2017b). Peranan perkembangan BPRS dalam kurun waktu tiga tahun terakhir terhitung 2015-2018 memberikan dampak yang cukup baik, dari jumlah 163 di tahun 2015 mengalami peningkatan jumlah menjadi 168 di tahun 2018 (OJK, Statistik Perbankan Syariah). Hal ini tentu menandakan semakin diminatinya perbankan syariah oleh masyarakat, sehingga pelayanan yang diberikan dapat dirasakan oleh masyarakat disuatu wilayah atau daerah yang belum mengenal atau merasa belum mengetahui perbankan syariah.

BPRS memiliki peran cukup besar pada perekonomian di Indonesia terbukti dalam empat tahun terakhir pembiayaan yang dikeluarkan oleh BPRS berdasarkan golongan pembiayaannya mengalami peningkatan yang cukup pesat. Ditahun 2014 terdapat pembiayaan sebesar Rp3,0 triliyun untuk pembiayaan Usaha kecil dan Menengah (UKM) dan Rp1,9 triliyun untuk selain UKM dengan total keseleluruhan mencapai Rp5,0 triliyun. Perkembangan meningkat ditahun 2015 dimana total pembiayaan yang dikeluarkan Rp5,7 triliyun, ditahun 2016 kembali naik menjadi Rp6,2 triliyun hingga ditahun 2017 mengalami perkembangan yang cukup baik mencapai Rp7,7 triliyun (Husaeni, 2017c).

Besarnya pembiayaan yang dikeluarkan beserta modal dan aset yang dimiliki tidak lain adalah untuk mendapatkan laba yang memang menjadi tujuan dari setiap pebankan. Oleh karenanya kecukupan modal yang dimiliki suatu BPRS haruslah kuat semakin tinggi rasio kecukupan modal suatu perbankan syariah maka akan berfungsi untuk menampung risiko kerugian yang disebabkan oleh pembiayaan yang macet $(N P F)$. Variabel Capital Adequacy Ratio (CAR) merupakan ratio kecukupan modal yang dimiliki perbankan syariah terhadap risiko 
yang mungkin dihadapinya. Menurut Peraturan Bank Indonesia Nomor 14/18/PBI/2012, Capital Adequacy Ratio mempunyai nilai minimal sebesar 8\%. Semakin tingginya CAR dimiliki suatu perbankan maka bank tersebut dapat melakukan kegiatan pembiyaan yang bersifat operasional serta memberikan kontribusi positif bagi tingkat kesehatan bank. Tingginya rasio modal yang dimiliki bank dapat melindungi deposan, meningkatkan kepercayaan masyarakat kepada bank yang pada akhirnya dapat meningkatkan pendapatan pada bank. Dengan kata lain, semakin kecil risiko yang dihadapi suatu bank semakin besar keuntungan yang diperoleh bank.

BOPO diartikan sebagai hasil perbandingan antara total biaya operasional dan total pendapatan operasional. Rasio BOPO menunjukkan efisiensi bank dalam menjalankan salah satu fungsi pokoknya yaitu kredit atau pembiayaan, dimana bunga kredit menjadi pendapatan terbesar perbankan. Pengelolaan pembiayaan sangat diperlukan oleh bank, mesti demikian pengelolaannya haruslah dilakukan dengan sangat baik, mengingat fungsi pembiayaan sebagai penyumbang pendapatan terbesar bagi bank syariah. Tingkat kesehatan pembiayaan (NPF) ikut mempengaruhi pencapaian laba bank. Tingginya rasio BOPO, mengakibatkan kesehatan bank semakin menurun. Sebaliknya, semakin rendah tingkat rasio BOPO berarti semakin baik kesehatan bank tersebut (Riyadi, 2006).

Berdasarkan Kamus (Kodifikasi Peraturan Bank Indonesia, 2012) Non Performing Fianancing (NPF) merupakan kredit bermasalah yang terdiri dari kredit yang diklarifikasi kurang lancar, diragukan dan macet. Tingkat kredit bermasalah yang dialami oleh seluruh perbankan syariah masih menjadi persoalan yang sulit diatasi. Berdasarkan data Otoritas Jasa Keuangan (OJK), lonjakan Non Performing Financing $(N P F)$ di bank syariah telah melampaui batas maksimum 5\%, alias mencapai 5,54\%. Hal ini tentu menjadi warning bagi pelaku bank syariah dalam menjaga kualitas kreditnya.

\section{B. Metodologi Penelitian}

1. Pendekatan Penelitian

Menurut Jhon W Creswell (Creswell, 2017) pendekatan kuantitatif adalah metode-metode untuk menguji teori-teori (theories) dengan cara meneliti hubungan antarvariabel. Penelitian pengaruh CAR dan BOPO terhadap NPF ini menggunakan 
pendekatan kuantitatif. Dimana peneliti ingin mengetahui seberapa besar pengaruh variabel bebas (independent) yaitu CAR dan BOPO terhadap variabel terikat (dependent) yaitu NPF melaui subjek atau objek penelitian yang diteliti berdasarkan pada perhitungan angka-angka, statistik dari variabel yang digunakan.

2. Identifikasi Variabel

Variabel indepen pada penelitian ini adalah Capital Adequacy Ratio (CAR), Biaya Operasional Per Pendapatan Operasional (BOPO). Sedangkan variabel dependen yang digunakan adalah Non Performing Financing (NPF).

3. Definsi Operasional

Adapun definisi opersional pada penelitian ini adalah:

a. Capital Adequacy Ratio (CAR)

CAR merupakan rasio kecukupan modal yang berfungsi untuk menanggulangi kerugian-kerugian dalam perbankan yang disebabkan oleh aktiva pembiayaan berisiko. CAR merupakan variabel independen pertama dalam penelitian ini dan nilai CAR diperoleh dari Statistik Perbankan Syariah tahunan mulai dari Januari 2014 hingga Desember 2018 dengan skala pengukuran dalam nilai CAR ini menggunakan skala rasio.

b. Biya Operasional Per Pendapatan Operasional (BOPO)

BOPO adalah rasio perbandingan pengukur kemampuan manajemen bank dalam melakukan kegiatan operasinya ditinjau dari pengelolaan biaya operasional terhadap pendapatan operasional. BOPO merupakan variabel independen kedua dalam penelitian ini dan nilai BOPO diperoleh dari Statistik Perbankan Syariah tahunan mulai dari Januari 2014 hingga Desember 2018 dengan skala pengukuran dalam nilai BOPO ini menggunakan skala rasio.

c. $\quad$ Non Performing Financing (NPF)

NPF merupakan rasio risiko kredit bermasalah yang diklasifikasikan kurang lancar, diragukan dan macet dengan menunjukan kemamapuan bank dalam mengelola risiko kredit yang diberikannya kepada pihak ketiga. NPF merupakan variabel dependen dalam penelitian ini dan nilai NPF diperoleh dari Statistik Perbankan Syariah tahunan mulai dari Januari 2014 hingga 
Desember 2018 dengan skala pengukuran dalam nilai NPF ini menggunakan skala rasio.

4. Jenis dan Sumber Data

Dalam penelitian ini seluruh data yang diperoleh merupakan data sekunder yang diperoleh dari situs resmi Otoritas Jasa Keuangan (OJK) yakni www.ojk.go.id. Data yang digunakan berupa data time series (runtutan waktu) tahunan mulai Januari 2014 hingga Desember 2018 dengan skala rasio

5. Populasi dan Sampel

Dalam penelitian ini populasi yang digunakan adalah seluruh Bank Pembiayaan Rakyat Syariah di Indonesia. Penelitian ini dimulai pada Januari 2014 hingga Desember 2018 yakni sebanyak 60 periode atau 5 tahun. Teknik penentuan sampel yang digunakan dalam penelitian ini adalah teknik purposive sampling. Teknik purposive sampling adalah teknik penentuan sampel dengan pertimbangan tertentu. Adapun pertimbangan yang diambil dari penelitian ini adalah pada kelengkapan data tahunan dari variabel-variabel penelitian yang tersaji dalam Statistik Perbankan Syariah yang dipublikasi secara resmi oleh OJK dalam situsnya. 6. Teknik Analisis Data

Teknik analisis dalam penelitian ini menggunakan teknik analisis regresi linier berganda. Langkah pertama dalam teknik analisis regresi linier berganda sebelum persamaan model regresi terbentuk adalah melakukan uji asumsi klasik yakni uji normalitas, uji autokorelasi, uji multikolinieritas, dan uji heteroskedisitas. Setelah seluruh uji asumsi klasik terpenuhi, maka langkah selanjutnya adalah menentukan koefisien determinasi (R2) dan uji hipotesis yakni uji F dan uji t. Uji F digunakan untuk menguji pengaruh simultan variabel independen terhadap variabel dependen, sedangkan uji t digunakan untuk menguji pengaruh secara parsial variabel independen terhadap variabel dependen. Seluruh data diolah dengan menggunakan bantuan perangkat lunak (software) IBM SPSS v 24.

\section{Hasil dan Pembahasan}

1. Deskripsi CAR

Veriabel CAR dari Januari 2014 sampai Desember 2018 terjadi fluktuasi.

Pada bulan Januari 2014 CAR berada diangka 24,62 \% hingga pada bulan Desember 2014 terjadi penurunan sebesar 22,77\%. Pada tahun 2015 pun terjadi 
keanikan dan penurunan atau fluktuasi dalam laporan keuangan CAR pada BPRS. Pada bulan Januari 2015 hingga Februari 2015 kenaikan dari 24,63\% menjadi 24,67\%, sedangkan pada bulan Maret 2015 hingga September 2015 mengalami penurunan dari $23,04 \%$ menjadi $20,71 \%$.

Pada tahun berikutnya Januari 2016 hingga Agustus 2016 CAR mengalami penurunan dari 23,48 \% menjadi 20,24\% pada bulan September hingga Desember masih terjadi kenaikan dan penurunan hingga pada bulan Desember kembali naik menjadi 21,73 \%yang semula di bulan September 20,72\%.

Di bulan Januari 2017 hingga Mei 2017 CAR mengalami penurunan dari 23,46 \% sampai 20,57 \% dan pada bulan Juni 2018 sampai bulan November kembali naik dari 20,62 \% sampai 20,93 \%. Sedangkan pada bulan Januari 2018 sampai bulan Juli 2018 CAR mengalami penurunan dari yang semula 22,05\% sampai $19,76 \%$.

\section{Deskripsi BOPO}

BOPO BPRS dari Januari 2014 sampai Desember 2018 terjadi kenaikkan dan penurunan atau fluktuasi. Pada bulan Januari 2014 sampai Juni 2014 mengalami penurunan dari 89,48 \% sampai 87,51\%. Sedangkan pada bulan Juli 2014 sampai Desember 2014 pun kembali mengalami penurunan dari 89,77\% sampai $87,79 \%$.

Pada bulan Januari 2015 sampai Juli 2015 BOPO mengalami kenaikkan dari 88,03 \% sampai 89,24 \% sedangkan pada bulan Agustus sampai Desember 2018 cenderung terlihat fluktuasi. Di bulan Januari 2016 hingga desember 2016 BOPO cenderung mengalami penurunan dari $91,89 \%$ sampai $87,09 \%$ walau di bulan Agustus 2016 terlihat sempat naik yaitu 89,42 \% namun di bulan bulan berikutnya hingga desember 2016 kembali mengalami penurunan.

Pada bulan Januari 2017 sampai Juli 2017 BOPO mengalami kenaikan dari 83,46 \% sampai 86,05 \% dan pada bulan berikutnya bulan Agustus sampai Desember terjadi penurunan dari $86,18 \%$ sampai $85,34 \%$. Sedangkan di bulan Januari 2018 hingga Desember 2018 tejadi kenaikan dan penurunan pada BOPO dari $83,75 \%$ sampai $87,66 \%$.

\section{Deskripsi NPF}

Copyright ( 2 2021, Ar-Rihlah: Jurnal Keuangan dan Perbankan Syariah Fakultas Ekonomi dan Bisnis Islam Universitas Suryakancana 
NPF dari Januari 2014 sampai Desember 2018 terjadi fluktuasi. Pada bulan Januari 2014 sampai November 2014 mengalami kenaikan dari 7,77 \% menjadi 8,81\%. Sedangkan pada bulan Desember 2014 terjadi penurunan sebesar 7,89\%. Pada tahun 2015 terjadi kenaikan dan penuruanan dalam laporan NPF di BPRS. Pada bulan Januari sampai Maret 2015 mengalami kenaikan dari 8,97 \% menjadi 10,36 \% sedangkan pada bulan Maret sampai September 2015 terjadi penurunan dari 10,36 \% menjadi 9,87 \%. Pada bulan Januari sampai November 2016, NPF mengalami kenaikan dari 9,08 \% menjadi 10,13\% pada bulan Desember turun kembali menjadi 8,63\%. Sedangkan pada Januari 2017 sampai Oktober 2017 NPF mengalami kenaikan dari 9,98 \% sampai 10,90\% dan pada bulan November 2017 sampai Desember 2017 NPF kembali turun dari 10,81 menjadi 9,68 \%. Sedangkan pada bulan Januari 2018 sampai Oktober 2018 NPF mengalami kenaikan dari 11,21 $\%$ sampai 11,35 \% dan mengalami penurunan kembali pada bulan November sampai Desember dari 10,94\% sampai 9,30\%.

\section{Pengajuan Asumsi Klasik}

1. Uji Normalitas

Menurut Ghozali (2005) dalam (V. Wiratna Sujarweni, 2018) Uji Nomalitas bertujuan untuk mengujui apakah dalam model regresi, variabel pengganggu atau residual memiliki distribusi normal. Untuk menguji data bersifat normal atau tidak maka peneliti menggunakan analisa one sample kologrov-smirnov dan P-P Plot sebagaimana berikut:

Tabel 1

Uji Normalitas

One-Sample Kolmogorov-Smirnov Test

\begin{tabular}{|ll|r|}
\hline $\mathrm{N}$ & $\begin{array}{c}\text { Standardized } \\
\text { Residual }\end{array}$ \\
Normal Parameters & & 60 \\
& Mean & .0000000 \\
Most Extreme Differences & Std. Deviation & .98290472 \\
& Absolute & .107 \\
& Positive & .086 \\
Test Statistic & Negative & -.107 \\
& & .107 \\
\hline
\end{tabular}

Copyright ( ) 2021, Ar-Rihlah: Jurnal Keuangan dan Perbankan Syariah Fakultas Ekonomi dan Bisnis Islam Universitas Suryakancana Pengaruh Capital Adequacy Ratio (Car) Dan Biaya Operasional Per Pendapatan Operasional (Bopo) Terhadap Non Performing Financing (Npf) Di Bprs Indonesia Periode 2014-2018 
Asymp. Sig. (2-tailed)

a. Test distribution is Normal.

b. Calculated from data.

c. Lilliefors Significance Correction.

Sumber: ouput IBM SPSS v 24

Berdasarkan Tabel 1 di atas, menunjukan angka nilai residual di pereoleh 0,082 >0,05 signifikan residualnya bersifat normal. Adapun hasil dari pengujian normal P-P Plot dapat dilihat pada gambar dibawah ini.

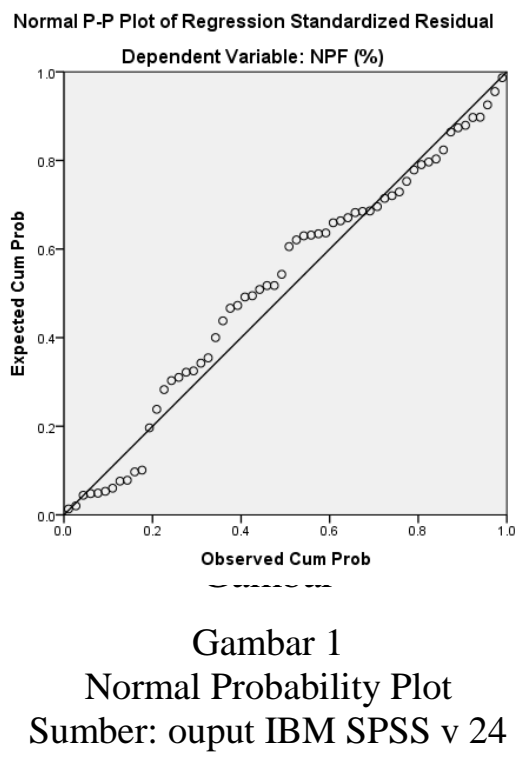

Berdasarkan gambar di atas terlihat titik-titik yang berbentuk menyebar di sekitar garis diagonal. Hal ini menunjukan berarti data berdistribusi normal. Maka dapat disimpulkan berdasarkan tabel 1 dan gambar 1 di atas data yang diperoleh menunjukan distribusi normal.

\section{Multikolinearitas}

Uji multikolinearitas bertujuan untuk menguji apakah dalam model regresi yang terbentuk ada korelasi yang tinggi atau sempurna diantara variabel bebas atau tidak. Model regresi yang baik menunjukan tidak terjadinya korelasi diantara variabel bebas. Untuk menguji gejala multikolinearitas dalam regresi adalah dengan melihat nilai tolerance dan Variance Inflation Factor (VIF) dari masing-masing variabel bebas terhadap variabel terikatnya. Apabila nilai VIF masing-masing variabel independen kurang dari 10 (VIF < 10), maka model regresi terbebas dari masalah multikolinieritas. Adapun hasil uji multikolenaritas adalah sebagai berikut: 
Tabel 2

Uji Multikolinearitas

\begin{tabular}{|c|c|c|}
\hline Variabel Independen & Nilai VIF & Kesimpulan \\
\hline CAR & 1.058 & Bebas Multikolinearitas \\
\hline BOPO & 1.058 & Bebas Multikolinearitas \\
\hline
\end{tabular}

Sumber: output IBM SPSS v 24

\section{Uji Autokolerasi}

Menurut Nacrowi dan Usman (2002) dalam (V. Wiratna Sujarweni, 2015) menguji autokrelasi dalam suatu model bertujuan untuk mengetahui ada tidaknya korealsi antara variabel pengganggu pada periode tertentu dengan variabel sebelumnya. Cara mendeteksi autokorelasi dengan menggunakan Durbin Watson adalah sebagai berikut:

1) Angka D-W dibawah -2 berarti ada autokorelasi positif

2) Angka $D-W$ diantara -2 dan +2 berarti tidak autokorelasi

3) Angka D-W diatas -2 berarti ada autokorelasi negatif.

Hasil dari Uji Autokorelasi dalam penelitian ini adalah sebagai berikut:

Tabel 3

Uji Autokorelasi

Model Summary ${ }^{b}$

\begin{tabular}{|c|c|c|c|c|c|}
\hline Model & $\mathrm{R}$ & R Square & $\begin{array}{l}\text { Adjusted R } \\
\text { Square }\end{array}$ & $\begin{array}{c}\text { Std. Error of the } \\
\text { Estimate }\end{array}$ & Durbin-Watson \\
\hline 1 & $.776^{a}$ & .603 & .589 & .72742 & 1.257 \\
\hline
\end{tabular}

a. Predictors: (Constant), BOPO (\%), CAR (\%)

b. Dependent Variable: NPF (\%)

Sumber: output IBM SPSS v 24

Berdasarkan tabel 3 di atas dapat diketahui nilai D-W sebesar 1,257, nilai tersebut berada diantar -2 dan +2 . Maka dapat disimpulkan bahwa data tersebut tidak terjadi autokorelasi.antara CAR dan BOPO terhadap NPF. 


\section{Uji Heteroskedasitas}

Uji Heteroskedasitas dilakukan untuk mengetahui apakah terjadi perbedaan residual suatu periode pengamatan ke periode pengamatan yang lain. Untuk mengetahui adanya gejala heteroskedasitas dalam model persamaan regresi dapat dilihat dengan pola gambar scatterplot melaui program SPSS. Jika titik-titik data menyebar di bawah dan di atas angka nol, titik-titik data tidak megumpul hanya di atas atau di bawah saja, dan penyebaran titik-titik data tidak berpola (Wiratna Sujarweni 2015: 235).

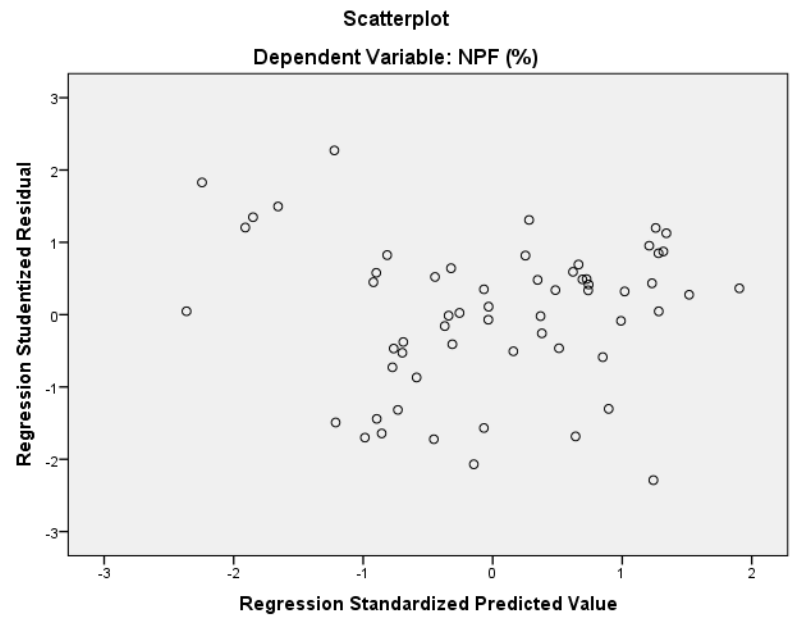

Gambar 2

Uji Heteroskedasitas Berdasarkan Tabel Scatterplot Sumber: ouput IBM SPSS v 24

Berdasarkan gambar 4.2 di atas terlihat titik-titik menyebar secara acak serta tersebar di sekitar titik 0 . Serta tidak ada pola tertentu yang bersifat teratur, oleh karena itu, dapat disimpulkan bahwa tidak terjadi heteroskedasitas model regresi tersebut.

5. Uji Koefisien Determinasi dan Pengujian Hipotesis

Tabel 4

Uji Koefisien Determinasi

Model Summary

\begin{tabular}{|l|r|r|r|r|r|}
\hline Model & $\mathrm{R}$ & R Square & \multicolumn{1}{c|}{$\begin{array}{c}\text { Adjusted } \mathrm{R} \\
\text { Square }\end{array}$} & $\begin{array}{c}\text { Std. Error of the } \\
\text { Estimate }\end{array}$ & Durbin-Watson \\
\hline 1 & $.776^{\mathrm{a}}$ & .603 & .589 & .72742 & 1.257 \\
\hline
\end{tabular}

a. Predictors: (Constant), BOPO (\%), CAR (\%) 
b. Dependent Variable: NPF (\%)

Sumber: output IBM SPSS V 24

Berdasarkan tabel 4 diatas, besarnya $\mathrm{R}$ square dalam model regresi ini diperoleh sebesar 0,603 sehingga nilai koefisien determinasi yang diperoleh adalah sebagai berikut:

$$
\begin{gathered}
\mathrm{KD}=\mathrm{r}^{2} \times 100 \% \\
\mathrm{KD}=603 \times 100 \%=60,3 \%
\end{gathered}
$$

Hal ini menunjukkan nilai $\mathrm{R}$ (koefisien korelasi) sebesar 0,776. Hal ini berarti bahwa hubungan antara variabel bebas dan terikat sebesar 77,6\%. Besarnya nilai $\mathrm{R}$ Square $\left(\mathrm{R}^{2}\right)$ sebesar 0,603 . Hal ini berarti menerangkan kemampuan variabel independent dalam menerangkan variansi peerubahan variabel dependen sebesar 60,3\% sedangkan sisanya 39,7\% diterangkan oleh faktor-faktor lain yang tidak dijelaskan dalam penelitian ini. Pengujian hipotesis untuk uji t dan uji $\mathrm{F}$ adalah sebagai berikut:

a. Variabel capital adequacy ratio (CAR) memperoleh hasil uji dengan nilai t hitung $-7,371>\mathrm{t}$ tabel $-1,672$. Hal ini menunjukkan bahwa Ho ditolak dan Ha diterima dan nilai signifikannya $0,00<0,05$ dengan demikian pula $\mathrm{Ha}$ diterima Ho ditolak, maka dapat disimpulkan variabel CAR berpengaruh signifikan kearah negatif terhadap NPF;

b. Variabel Biaya Operasional Per Pendapatan Operasional (BOPO) memperoleh hasil uji dengan nilai $\mathrm{t}$ hitung $-3.778>\mathrm{t}$ tabel $-1,672$. Hal ini menunjukkan bahwa Ho ditolak dan Ha diterima dan nilai signifikannya $0,00<0,05$ dengan demikian pula Ha diterima Ho ditolak, maka dapat disimpulkan variabel BOPO berpengaruh signifikan kearah negatif terhadap NPF;

c. Diperoleh $F_{\text {hitung }}$ sebesar 43,223 > Ftabel 3,160 dan nilai signifikansinya $0,000<0,005$. Hal ini berarti menunjukkan bahwa semua variabel independen yaitu CAR dan BOPO berpengaruh signifikan terhadap NPF maka Ha diterima Ho ditolak.

\section{Kesimpulan}


Berdasarkan uji asumsi klasikk yang telah yang dilakukan dapat disimpulkan bahwa seluruh uji asumsi klasik telahh terpuhi, terlihat dari nilai $\mathrm{R}^{2}$ pada penelitian sebesar $60,3 \%$, sedangkan $39,7 \%$ dipengaruhi oleh variabel lain diluar model yang diteliti. Variabel lain tersebut dapat berupada FDR, ROA, dan Inflasi. Adapun uji Hipotesis dalam penelitian ini akan dijelaskan sebagai berikut:

1. Pengaruh CAR Terhadap NPF

Berdasarkan hasil pengujian parsial yang dilakukan, diketahui variabel CAR berpengaruh terhadap NPF hal ini dapat dilihat berdasarkan perolehan uji t yang menunjukkan hasil nilai -7,371 > -1,672 dengan probabilitas kesalahannya $0,00<0,05$ dengan demikian Ho ditolak dan Ha diterima. Hal ini menunjukkan bawah CAR berpengaruh kearah negatif dan signifikan terhadap NPF. Artinya setiap CAR mengalami kenaikan ataupun penuruanan sedangkan NPF akan berubah secara signifikan. Sebagaimana menurut (Pratiwi, 2012) hasil penelitiannya menunjukkan bahwa CAR berpengaruh negatif tidak signifikan terhadap ROA. Menurut (Fahmy, 2013) CAR berpengaruh positif tetapi tidak signifikan terhadap ROA. Meskipun terdapat perbedaan diantara variabel dependent namun penelitian tersebut dapat dijadikan acuan perbandingan atau pendukung dari penelitian yang dilakukan oleh peneliti.

2. Pengaruh BOPO Terhadap NPF

Berdasarkan hasil dari penelitian, diketahui pengaruh variabel BOPO terhadap NPF (Non Performing Financing) berdasarkan perolehan uji t yang menunjukkan hasil sebesar $-3.778>-1,672$ dan signifikansiya sebesar $0,000<0,05$. Hal ini berarti menunjukkan rasio variabel BOPO berpengaruh signifikan dan mempunyai arah negatif terhadap NPF di BPRS Indonesia.

Dalam penelitian ini kriteria penilaian BOPO berada pada peringkat kurang dari $94 \%$, hal ini dapat dilihat rata-rata nilai rasio BOPO sebesar 87,472\% ,maka dari itu dapat disimpulkan bahwa rasio BOPO di BPRS seluruh Indonesia periode 2014 sampai 2018 sangat efisien dalam mengendalikan biaya operasionalnya, sehingga kinerja keuangan di BPRS Indonesia semakin baik. Sehingga dalam penelitian ini dapat disimpulkan bahwa variabel BOPO berpengaruh negatif signifikan terhadap NPF. 
3. Pengaruh CAR dan BOPO Terhadapt NPF

Uji simultan menyatakan bahwa CAR dan BOPO berpengaruh terhadap

NPF dengan nilai value lebih kecil dari a $(0,000<0,005)$ Hal ini berarti menunjukkan bahwa semua variabel independen yaitu CAR dan BOPO berpengaruh secara bersama-sama terhadap NPF.

\section{Referensi}

\section{Buku, Artikel, Skripsi}

Creswell, W. J. (2017). Research Design Pendekatan Kualitatif, Kuantitatif dan Campuran. Cetakan II. Pustaka Belajar.

Fahmy, M. S. (2013). Capital Adequacy Ratio (CAR), Non Performing Financing (NPF), Biaya Operasional terhadap Pendapatan Operasional (BOPO), dan Financing to Deposit Ratio (FDR) terhadap Profitabilitas Bank Umum Syariah.

Husaeni, U. A. (2017a). Analisis Pengaruh Dana Pihak Ketiga Dan Non

Performing Financing Terhadap Return On Asset Pada BPRS Di Indonesia.

Equilibrium: Jurnal Ekonomi Syariah, 5(1), 1-16.

Husaeni, U. A. (2017b). Determinan Pembiayaan Pada Bank Pembiayaan Rakyat Syariah di Indonesia. Esensi, 7(1), 49-62.

https://doi.org/10.15408/ess.v7i1.4542

Husaeni, U. A. (2017c). Ekspansi D ETERMINAN P ROFITABILITAS. Ekspansi, 9(1), 155-163.

Kodifikasi Peraturan Bank Indonesia. (2012). Kodifikasi Peraturan Bank Indonesia Kelembagaan Penilaian Tingkat Kesehatan Bank tahun 2012.

Pratiwi, D. D. (2012). Pengaruh CAR, BOPO , NPF dan FDR Terhadap Return Of Asset di Bank Umum Syariah Periode 2005-2010.

Riyadi, S. (2006). Banking Asset and Liability Management. Lembaga Penerbit Fakultas Ekonomi Universitas Indonesia.

V. Wiratna Sujarweni. (2015). Metodologi Penelitian Bisnis dan Ekonomi. PUSTAKABARUPRESS.

V. Wiratna Sujarweni. (2018). Metodologi Penelitian Bisnis dan Ekonomi Pendekatan Kuantitatif. PUSTAKABARUPRESS.

\section{Website}

OJK 2017. Laporan Perkembangan Keuangan Syariah Indoensia 2018. http://www.ojk.go.id diunduh pada tanggal 24 Maret 2019 